\title{
Studies on Hexokinase
}

\section{AN ACTIVATOR OF HEXOKINASE IN MUSCLE EXTRACTS}

\author{
By H. WEIL-MALHERBE AND A. D. BONE \\ Research Department, Runwell Hospital, Wickford, Essex
}

(Received 13 November 1950)

It has been shown in the preceding paper (WeilMalherbe \& Bone, 1951b) that there exists in red blood cells an activator of the hexokinase reaction which could not be identified with any of several factors known to be parts of the glycolytic system. It will now be shown that a similar or identical factor is present in muscle. In view of the difficulties which were encountered in the attempts to purify the erythrocyte factor, emphasis in this study was laid on fractionation experiments. Fractions were obtained which showed maximal activity in concentrations of the order of $1 \mathrm{mg} . / 3 \mathrm{ml}$.

\section{METHODS}

Most of the methods used in this investigation were fully described in the first two papers of this series (Weil-Malherbe \& Bone, $1951 a, b)$. Additional information is given below.

Measurement of the activating effect. To avoid any interference by muscle hexokinase all fractions which were to be tested for their activating properties were heated at $56^{\circ}$ for 5 min., a treatment which practically destroys all hexokinase activity. No further mention will be made of this in the following sections, unless it is to be contrasted with other heat treatments.

The activating effect was measured by the increase in the rate of glucose disappearance caused by the addition of fractions of rabbit-muscle extract to rat-brain extract, and expressed in relation to the activity of the control experiment containing rat-brain extract only. The activity of the control experiment was designated by 100 .

Measurement of phosphohexokinase activity. Phosphohexokinase activity was measured manometrically and/or by the estimation of hexosediphosphate formation. The test solution contained, in addition to the enzyme, the usual mineral constituents, adenosinetriphosphate (ATP) and hexosemonophosphate in the same concentrations as used for the estimation of hexokinase activity, unless otherwise stated.

Measurement of adenylic deaminase activity. The test solution contained $\mathrm{MgCl}_{2}$ and $\mathrm{NaHCO}_{3}$ in the usual concentrations and 10 or $20 \mu \mathrm{mol}$. adenylic acid/3 ml. Deamination was determined by the increase of $\mathrm{NH}_{3}$ after incubation with the enzyme.

Measurement of adenosinetriphosphatase (ATP-ase) activity. The enzyme was determined by the formation of inorganic phosphate from ATP (10 $\mu$ mol.) in a solution containing $\mathrm{MgCl}_{2}$ and $\mathrm{NaHCO}_{3}$ in the usual concentrations.

All experiments were carried out at $30^{\circ}$ in an atmosphere of $\mathrm{N}_{2}$ containing $5 \%(\mathrm{v} / \mathrm{v}) \mathrm{CO}_{2}$ for periods of 10,20 or $30 \mathrm{~min}$. Estimations of metabolites (except glucose and fructose) were performed on trichloroacetic acid filtrates (final concentration 3-5\% w/v).

Protein was estimated with Folin \& Ciocalteu's phenol reagent (1927).

Other experimental procedures are described in the following section.

\section{RESULTS}

\section{Fractionation experiments}

The starting material for further fractionation was an extract of chilled rabbit muscle prepared by homogenizing 1 vol. of tissue with 2 vol. of $0.033 \mathrm{M}-\mathrm{NaHCO}_{3}$ solution in an Atomix blender (Measuring and Scientific Equipment Ltd., London, S.W. 1) for 2-3 min. The homogenate was gently stirred at $0^{\circ}$ for $30 \mathrm{~min}$. and strained through surgical lint. The extract was finally clarified by filtration through a layer of kieselguhr on a Büchner funnel. Further fractionation was carried out either by $\left(\mathrm{NH}_{4}\right)_{2} \mathrm{SO}_{4}$ addition or by isoelectric precipitation at $\mathrm{pH} 5 \cdot 6$.

Ammonium sulphate fractionation. The following fractions were collected: (1) $0-0 \cdot 2$, (2) $0.2-0.3$, , (3) $0.3-0.4$, (4) $0.4-0.5$ and (5) 0.5-1.0 saturation. The first four fractions were precipitated by saturated $\left(\mathrm{NH}_{4}\right)_{2} \mathrm{SO}_{4}$ solution adjusted to $\mathrm{pH} 7 \cdot 6$ with $\mathrm{NH}_{3}$ and the last fraction by the addition of solid $\left(\mathrm{NH}_{4}\right)_{2} \mathrm{SO}_{4}$. The centrifuged fractions were washed once with $\left(\mathrm{NH}_{4}\right)_{2} \mathrm{SO}_{4}$ solutions of the requisite strength and dissolved in a small volume of $0.01 \mathrm{~m}$-ammonium phosphate buffer (pH 7.6).

On dialysis in cellophan at $0^{\circ}$ against distilled water (six to seven changes) fraction 1 formed an opalescent solution, whereas fractions 3-5 separated into a clear solution and a precipitate. Fraction 2 remained opalescent although a small precipitate was formed. The precipitates were centrifuged off, washed with distilled water and redissolved in phosphate buffer. These fractions were designated by the suffix $P$, the supernatant fractions by the suffix $S$.

In agreement with the results obtained by $\left(\mathrm{NH}_{4}\right)_{2} \mathrm{SO}_{4}$ fractionation of haemolysates (Weil-Malherbe \& Bone, $1951 b$ ) it was found that the activator of hexokinase appeared in several fractions. It was strongest in fractions 1 , $3 P$ and $4 P$, less strong in fractions $2 P$ and $5 P$ and weak or absent in fractions $2 S, 3 S, 4 S$ and $5 S$. This pattern, of which an example is given in Table 1, was repeatedly confirmed. The activation effect increases with increasing amounts of the factor up to a saturation value which, in the case of fraction $3 P$, was reached with the addition of about $1 \mathrm{mg}$. (Fig. 1). The maximum activation in this experiment was a little less than twofold, but higher effects were sometimes observed, especially when the amount of brain extract was reduced (Table 2). Fig. 2 illustrates the course of the reaction in presence and in absence of activating factor (fraction $3 P$ ) as measured by the disappearance of glucose. 
Table 1. Activating effects of ammonium sulphate fractions of rabbit-muscle extract on rat-brain hexokinase

(1 mg. protein added to standard test.)

$\begin{array}{cc}\begin{array}{c}\text { Fraction } \\ \text { no. }\end{array} & \begin{array}{c}\text { Activating effect } \\ \text { (activity of control experiment }=100 \text { ) }\end{array} \\ 1 & 196 \\ 2 S & 128 \\ 2 P & 166 \\ 3 S & 134 \\ 3 P & 226 \\ 4 S & 107 \\ 4 P & 209 \\ 5 S & 98 \\ 5 P & 132\end{array}$

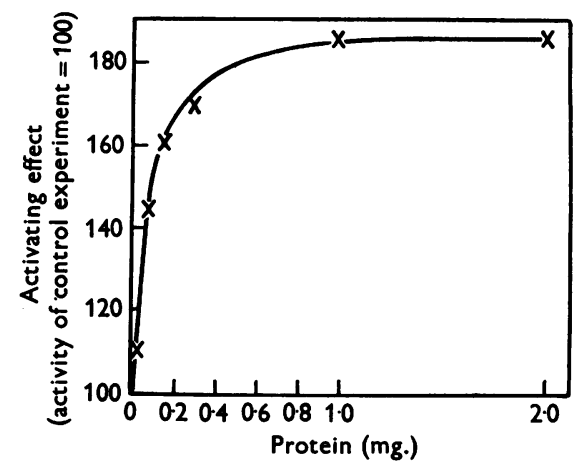

Fig. 1. Activating effect of fraction $3 P$ on rat-brain hexokinase.

Table 2. Activating effect of rabbit-muscle fraction $4 P(1 \mathrm{mg}$.) on dilute brain hexokinase $(0.5 \mathrm{mg}$. pratein $/ 3 \mathrm{ml}$.)

$\begin{array}{cc}\begin{array}{c}\text { Decrease in } \\ \text { glucose } \\ \text { (mg.) }\end{array} & \begin{array}{c}\text { Activating effect } \\ \text { (activity of } \\ \text { control =100) }\end{array} \\ \mathbf{0 . 0 8 0} & - \\ \mathbf{0} & - \\ \mathbf{0 . 3 8 3} & \mathbf{4 8 0}\end{array}$

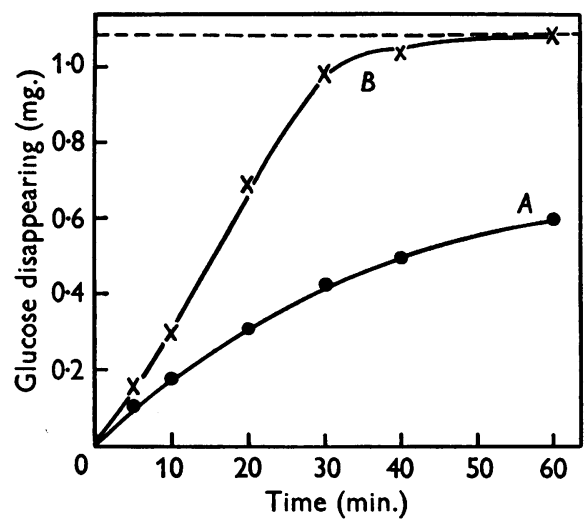

Fig. 2. Disappearance of glucose from rat-brain extract in presence and in absence of activating fraction $3 P$ from rabbit muscle. Curve $A$, brain extract; curve $B$, brain extract + fraction $3 P$ ( $1 \mathrm{mg}$. protein).
The fractions obtained by the addition of $\left(\mathrm{NH}_{4}\right)_{2} \mathrm{SO}_{4}$ were also tested for the presence of ATP-ase, adenylic deaminase and phosphohexokinase, and it appeared that their distribution closely followed that of the activating factor (Table 3 ).

Table 3. Enzyme activities in ammonium sulphate fractions of rabbit-muscle extract

$\begin{array}{cccc}\begin{array}{c}\text { Fraction } \\ \text { no. }\end{array} & \text { ATP-ase } & \begin{array}{c}\text { Adenylic } \\ \text { deaminase }\end{array} & \begin{array}{c}\text { Phospho- } \\ \text { hexokinase }\end{array} \\ \mathbf{1} & ++ & ++ & + \\ \mathbf{2} & ++ & ++ & + \\ \mathbf{3} S & 0 & 0 & (+) \\ \mathbf{3 P} & + & +++ & +++ \\ \mathbf{4 S} & 0 & 0 & 0 \\ \mathbf{4 P} & (+) & (+) & ++ \\ \mathbf{5 S} & 0 & 0 & 0 \\ \mathbf{5 P} & 0 & 0 & (+)\end{array}$

ATP-ase and adenylic deaminase activities were largely destroyed by heating at $56-60^{\circ}$ for $5 \mathrm{~min}$., but this treatment did not affect the activating factor and only moderately decreased phosphohexokinase activity. This last was completely abolished by heating at $80^{\circ}$ for 5 min.; at this temperature the activating effect was also reduced to some extent (Table 4). The activating factor present in these muscle fractions thus seems to be less heat-resistant than the haemolysate factor. A further difference is that the activity of the heated sample is contained in the supernatant, and not in the coagulated mass of denatured protein as in the case of the haemolysate (Table 4).

\section{Table 4. Heat stability of activating factor}

(5 mg. protein added to standard test.)

Fraction $3 P$

Heated at $56^{\circ}$ for $5 \mathrm{~min}$. 232

Heated at $80^{\circ}$ for $5 \mathrm{~min}$. 179

Heated with 0.05 vol. $\mathrm{N}-\mathrm{HCl}$ at $90^{\circ}$ for $\quad 52$

2 min., cooled and neutralized

Fraction 4P

Heated at $100^{\circ}$ for $10 \mathrm{~min}$., homogenized $\quad 146$

Heated at $100^{\circ}$ for 10 min., supernatant 139

Heated at $100^{\circ}$ for 10 min., coagulum

Isoelectric precipitation. An active preparation was also obtained by acidification of the muscle extract to $\mathrm{pH} \mathrm{5.6}$ with $\mathrm{N}$-acetic acid. The resulting voluminous precipitate was centrifuged, washed with distilled water and dissolved by adjustment to $\mathrm{pH} 7.5$ with $0.1 \mathrm{~N}-\mathrm{NaOH}$. A viscous, opalescent solution was thus obtained which had strong hexokinase, ATP-ase and adenylic deaminase activity, but contained only small amounts of phosphohexokinase. It was rich in activating factor, but somewhat higher amounts of protein, of the order of $5 \mathrm{mg}$., were necessary to reach the saturation value of the effect.

Attempts were made further to fractionate this material by salting-out techniques. By adding $\left(\mathrm{NH}_{4}\right)_{2} \mathrm{SO}_{4}$ solution to 0.2 saturation or $\mathrm{Na}_{2} \mathrm{SO}_{4}$ to $14 \%(\mathrm{w} / \mathrm{v})$ a bulky precipitate was obtained which consisted largely of denatured protein. By further fractionation of the supernatant and subsequent 


\section{Table 5. Heat stability of activating factor (isoelectric precipitate)}

(Samples heated in sodium phosphate buffer (0.01-M, $\mathrm{pH} \mathrm{7.5)}$ for $5 \mathrm{~min}$.)

\begin{tabular}{|c|c|c|c|c|}
\hline $\begin{array}{l}\text { Protein } \\
\text { added } \\
\text { (mg.) }\end{array}$ & $\begin{array}{c}\text { Temp. of } \\
\text { heat treatment } \\
\left({ }^{\circ}\right)\end{array}$ & Coagulation & Fraction & $\begin{array}{l}\text { Activating effect } \\
\text { (activity of } \\
\text { control = 100) }\end{array}$ \\
\hline $\begin{array}{l}1 \\
6 \\
1 \\
6\end{array}$ & $\begin{array}{l}56 \\
56 \\
80 \\
80\end{array}$ & $\begin{array}{l}E \\
z\end{array}$ & $\begin{array}{l}\text { Whole } \\
\text { Whole } \\
\text { Whole } \\
\text { Whole }\end{array}$ & $\begin{array}{l}193 \\
290 \\
169 \\
228\end{array}$ \\
\hline $\begin{array}{l}1 \\
1 \\
1 \\
1 \\
1\end{array}$ & $\begin{array}{r}60 \\
70 \\
80 \\
100\end{array}$ & $\begin{array}{l}\overline{-} \\
(+) \\
++\end{array}$ & $\begin{array}{l}\text { Whole } \\
\text { Whole } \\
\text { Whole } \\
\text { Whole }\end{array}$ & $\begin{array}{l}182 \\
161 \\
146 \\
156\end{array}$ \\
\hline 9 & 80 & + & $\begin{array}{l}\text { Whole } \\
\text { Supernatant } \\
\text { Coagulum } \\
\text { Supernatant, protein-free* }\end{array}$ & $\begin{array}{l}187 \\
197 \\
119 \\
104\end{array}$ \\
\hline
\end{tabular}

dialysis, fractions were obtained which corresponded to fractions $2,3 S, 4 S, 3 P$, and $4 P$ of the preceding paragraph. Increasing the $\left(\mathrm{NH}_{4}\right)_{8} \mathrm{SO}_{4}$ concentration above 0.5 saturation did not produce any further precipitate. The activating factor showed a very similar distribution pattern, being present in the new fractions $3 P$ and $4 P$ especially, but the activity per mg. protein was not greatly increased compared with the original isoelectric precipitate. It must be assumed, therefore, that a considerable part of the factor was lost with the denatured protein.

The addition of acetone to the solution of the isoelectric precipitate at $0^{\circ}$, up to a final concentration of $30 \%(v / v)$, led to the formation of a precipitate which, after dialysis, proved to contain activating factor together with hexokinase and phosphohexokinase. When this solution was further fractionated with $\left(\mathrm{NH}_{4}\right)_{2} \mathrm{SO}_{4}$, the bulk of the protein was again precipitated in denatured form by 0.2 saturation. With the remainder, fractions were obtained corresponding to nos. $1 S$ to $4 S$ and $1 P$ to $4 P$. None of these had any hexokinase activity, but activation was caused by the fractions corresponding to $1 S, 3 S, 4 S, 3 P$ and $4 P$. The fractions showed maximum activity in amounts of $0.3-0.5 \mathrm{mg}$. protein.

Heat stability of the activating factor in the isoelectricprecipitate fraction. The activating factor in the isoelectricprecipitate fraction seemed to be less heat-sensitive than that in the fractions obtained by $\left(\mathrm{NH}_{4}\right)_{2} \mathrm{SO}_{4}$ fractionation (Table 5). Heating at $80^{\circ}$ for 5 min. usually produced only an increase in opacity, but no outright coagulation. However, in a sample which had been kept at $0^{\circ}$ for about 1 month after saturation with capryl alcohol (octan-2-ol), coagulation did occur leaving a clear supernatant. The latter contained the whole of the activity, while the coagulated protein was inactive. After the removal of protein from the supernatant with trichloroacetic acid, activity was lost (Table 5).

The greater heat resistance of the erythrocyte factor may perhaps be attributed to the formation of a bulky precipitate or to the liberation of SH-groups in denatured protein. Addition of egg albumin to the muscle fraction before heating did not, however, increase the heat stability of the factor, although massive coagulation took place. Addition of glutathione, either before or after heating, was likewise without effect. Finally, surface-active agents, such as capryl alcohol or 'cetavlon' (cetyltrimethylammonium bromide), added before or after heating of the muscle fraction, generally did not influence the activating effect except when added to a fresh preparation of the isoelectricprecipitate fraction (see below).

Increase of activating effect on standing. It was found that the activating effect of a solution of the isoelectric precipitate increased on standing, but that the full effect could be obtained in the freshly prepared fraction by saturation with capryl alcohol. This is demonstrated by the following experiment (Table 6): immediately after preparation part of

\section{Table 6. Activation effect of isoelectric precipitate (7 $\mathrm{mg}$.)}

(For details of procedure see text.)

Activating effect

(activity of control $=100$ )

\begin{tabular}{|c|c|c|}
\hline \multirow{2}{*}{$\begin{array}{c}\text { Time after } \\
\text { preparation } \\
\text { (days) }\end{array}$} & \multicolumn{2}{|c|}{ Sacosivey or } \\
\hline & $\begin{array}{l}\text { Sterile } \\
\text { sample }\end{array}$ & $\begin{array}{c}\text { Sample saturated } \\
\text { with capryl alcohol }\end{array}$ \\
\hline $\begin{array}{l}1 \\
4 \\
6 \\
1\end{array}$ & $\begin{array}{r}127 \\
182 \\
187 \\
95\end{array}$ & $\begin{array}{c}238 \\
172 \\
191 \\
153 \\
\text { Sample }+3 \cdot 33 \text { vol. } \\
1 \%(w / v) \text { cetavlon } \\
146\end{array}$ \\
\hline
\end{tabular}

the solution was sterilized by passage through a Seitz filter and put under aseptic precautions, into a number of small sterile bottles. Another part was saturated with capryl alcohol. Both fractions were kept at $0^{\circ}$ and tested at various intervals. After 1 day the sterile fraction had only slight activity and only after 4 days was its activity equal to that of the capryl alcohol fraction. No capryl alcohol was added to the control since, according to Meyerhof \& Wilson (1948), capryl alcohol inhibits brain hexokinase. Cetavlon had an effect on the activating factor similar to that of capryl alcohol.

The hexokinase activity of the isoelectric precipitate fraction was at its maximum immediately after preparation and was stable for many days at $0^{\circ}$. It was not significantly affected by the addition of capryl alcohol or cetavlon.

Other muscle proteins. A preparation of rat myosin (Bailey, 1942) proved to be devoid of activating effects, 
though it possessed strong ATP-ase and adenylic deaminase activities. The deaminase was separated from myosin by dialysis against $0.02 \mathrm{M}$-ammonium acetate $(\mathrm{pH} 8)$ according to Kalckar (1947). This fraction had no activating properties either. These results are of interest, since they confirm the conclusion, based on heating experiments, that the activating effect is independent of the activities of these enzymes.

Similarly, myokinase, prepared by the method of Colowick \& Kalckar (1943), did not bring about any activation of brain hexokinase under the conditions of our experiments (Table 7). The preparation used was tested for activity

\section{Table 7. Effect of purified myokinase on the activity of brain hexokinase}

(For details see text.)

\begin{tabular}{|c|}
\hline $\begin{array}{l}\text { Myokinase } \\
\text { protein adde } \\
\text { (mg.) }\end{array}$ \\
\hline $\begin{array}{l}0.05 \\
0.5 \\
1.0\end{array}$ \\
\hline
\end{tabular}

Activating effect (activity of control $=100$ )

0.5
$1 \cdot 0$ 96
100
97

in presence of adenylic deaminase (fraction $3 P$ ) and found to cause rapid $\mathrm{NH}_{3}$ formation from adenosinediphosphato (ADP). Heating a preparation of activating factor (fraction $3 P$ ) with 0.05 vol. of $\mathrm{N}-\mathrm{HCl}$ under the conditions used for the purification of myokinase completely destroyed its activity; the fraction even caused inhibition after this treatment (Table 4).

\section{Effects of the activating factor of muscle}

In all essentials the effects of the muscle factor resembled those of the erythrocyte factor. The presence of an active ATP-ase and adenylic deaminase in some preparations of the factor caused a larger formation of inorganic $\mathrm{P}$ and $\mathrm{NH}_{3}$. The latter reaction leads to the formation of only about $1 \mathrm{~mol}$. $\mathrm{CO}_{2}$ per mol. glucose in manometric experiments, a fact which seemed puzzling until the correct explanation was found (Table 8). But the yield of hexosediphosphate (Table 8) and the utilization of $P_{7 \mathrm{~min}}$. (Table9) per mol.glucose was the

Table 8. Formation of carbon dioxide, ammonia and hexosediphosphate during glucose phosphorylation in brain extract containing activating factor of muscle (fraction 3P)

(Brain extract, $0.6 \mathrm{ml}$; glucose, $11.1 \mu \mathrm{mol}$; ATP $20 \mu \mathrm{mol}$; muscle fraction $3 P, 2 \mathrm{mg} . / 6 \mathrm{ml}$. Manometric reaction completed in $20 \mathrm{~min}$. Control experiment (without muscle fraction) completed in approx. 60 min.)

$\begin{array}{cccc}\mathrm{CO}_{2} & \Delta \mathrm{NH}_{3} & \Delta \text { Inorganic } \mathrm{P} & \Delta \mathrm{HDP} \\ (\mu \mathrm{mol} .) & (\mu \mathrm{mol} .) & (\mu \mathrm{mol}) & (\mu \mathrm{mol} .) \\ 10.90 & 12 \cdot 0 & 3.0 & 8 \cdot 2\end{array}$

Table 9. Phosphate balance of glucose phosphorylation by brain extract in presence of activating factor of muscle (isoelectric precipitate)

(Brain extract, $0.9 \mathrm{ml}$; glucose, 16.67 $\mu \mathrm{mol}$; ATP, $40 \mu \mathrm{mol}$; $21 \mathrm{mg}$. muscle protein $/ 10 \mathrm{ml}$. Duration of experiment, $20 \mathrm{~min}$.)

$\begin{array}{lc}\Delta \text { Glucose }(\mu \mathrm{mol} .) & -14 \cdot 0 \\ \text { Activating effect } & 195 \\ \text { (activity of control =100) } & 13 \cdot 7 \\ \Delta \text { Inorganic P }(\mu \mathrm{mol} .) & -41 \cdot 3 \\ \Delta \mathrm{P}_{\text {7 min. }}(\mu \mathrm{mol} .) & 27 \cdot 6 \\ \text { P utilized }(\mu \mathrm{mol} .) & -20 \cdot 6 \\ \Delta \text { ATP }(\mu \text { mol.) } & 13 \cdot 7 \\ \text { ATP utilized }(\mu \mathrm{mol} .) & 0 \\ \Delta \text { ADP }(\mu \mathrm{mol} .) & 1 \cdot 97 \\ \text { P utilized } & \end{array}$

same, and the only significant difference in presence of the muscle factor was that the reaction went to completion more quickly. The factor, like that of erythrocytes, is specific for hexokinase and does not affect phosphohexokinase (Table 10).

Table 10. Effect of muscle fractions on activity of rat-brain phosphohexokinase

(Hexosemonophosphate, 5.55 $\mathrm{mmol}$; ATP, $10 \mu \mathrm{mol} . / 3 \mathrm{ml}$. Duration of experiment, $20 \mathrm{~min}$.)

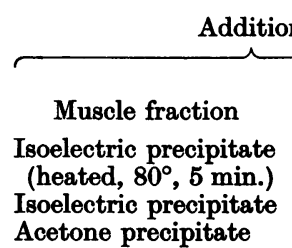

$\begin{array}{ccc}\begin{array}{c}\text { Activation } \\ \text { of brain } \\ \begin{array}{c}\text { hexokinase } \\ \text { (activity of } \\ \text { control =100) }\end{array}\end{array} & \begin{array}{c}\text { Without } \\ \text { addition }\end{array} & \begin{array}{c}\text { With muscle } \\ \text { fraction }\end{array} \\ 246 & 1.4 & 1.6 \\ 171 & 1.8 & 1.8 \\ 210 & 2.30 & 2.35\end{array}$

Table 11. Effect of the activating factor of muscle on hexokinase preparations of various origins

(Muscle extract and yeast hexokinase prepared and used as previously described (Weil-Malherbe \& Bone, 1951 $a, b$ ).)

\begin{tabular}{cc}
\multicolumn{2}{c}{ Addition } \\
Muscle fraction & $\begin{array}{c}\text { Protein } \\
\text { (mg.) }\end{array}$ \\
Fraction 3P & 5 \\
Isoelectric precipitate & 7 \\
Isoelectric precipitate & 7 \\
(heated, $80^{\circ}, 5$ min.) &
\end{tabular}

Activating effect (activity of control $=100$ ) on hexokinase of

$\begin{array}{ccc}\text { Muscle } & \text { Brain } & \text { Yeast } \\ 138 & 199 & - \\ - & 187 & 132 \\ - & 156 & 146\end{array}$


The effect can be demonstrated not only with brain hexokinase, but also with hexokinase preparations of different origin and a higher degree of purity (Table 11), although it seems that it is highest when brain extracts are used. It is not restricted to the action of hexokinase on glucose, but may also be observed during the phosphorylation of fructose in brain extracts (Table 12). Fructose, as has recently been shown (Slein, Cori \& Cori, 1950), is a substrate of brain hexokinase.

\section{Table 12. Effect of muscle fractions on phosphory-} lation of fructose by rat-brain extracts

(Fructose, 5.55 $\mu \mathrm{mol} . / 3 \mathrm{ml}$. Fructose estimated by method of Nelson (1944).)

\begin{tabular}{|c|c|}
\hline \multicolumn{2}{|c|}{ Addition } \\
\hline Muscle fraction & (mg.) \\
\hline $\begin{array}{l}\text { Isoelectric ppt. } \\
\text { Acetone ppt. }\end{array}$ & $\begin{array}{l}7 \\
3 \cdot 5\end{array}$ \\
\hline
\end{tabular}

Activating effect (activity of control =100) on phosphorylation of

$\begin{array}{cc}\text { Glucose } & \text { Fructose } \\ 278 & 206 \\ 192 & 177\end{array}$

yeast hexokinase, which is not inhibited by hexosemonophosphate, is activated by the factor also argues against a connexion between the activating effect and the inhibition due to hexosemonophosphate. Adenylic acid, an inhibitor of myokinase (Colowick \& Kalckar, 1943), has no effect on the activation of brain hexokinase by the muscle factor (Table 14).

Finally, as was previously found with erythrocyte factor, the activating factor does not increase the utilization of ADP in relation to that of ATP (Table 15).

\section{DISCUSSION}

\section{Similar factors mentioned in the literature}

Curtius \& Ohlmeyer (1938) reported on the existence of heat-stable, non-dialysable factors in muscle extract which activated lactic acid formation from glycogen. They did not identify the step at which the activation occurred but, as hexokinase was not involved, it is unlikely that their observations have any bearing on the factor described in these com-

Table 13. Effect of activating factor (isoelectric precipitate, heated at $80^{\circ}$ for 5 min.) on the inhibition of brain hexokinase by fructose-6-phosphate

$\begin{array}{ccc}\begin{array}{c}\text { Fructose- } \\ \begin{array}{c}\text { 6-phosphate } \\ \text { (mM) }\end{array}\end{array} & \begin{array}{c}\text { Decrease in } \\ \text { glucose } \\ \text { (mg.) }\end{array} & \begin{array}{c}\text { Inhibition } \\ (\%)\end{array} \\ 0 & 0.288 & - \\ 0.55 & 0.195 & 32 \\ 1.85 & 0.020 & 93 \\ \mathbf{5 . 5 5} & 0 & 100\end{array}$

Table 14. Effect of adenylic acid on the activating effect of isoelectric precipitate from muscle on brain hexokinase

(Isoelectric precipitate, $7 \mathrm{mg} . / 3 \mathrm{ml}$.)

\begin{tabular}{ccc}
$\begin{array}{c}\text { Adenylic acid } \\
\text { added }\end{array}$ & \multicolumn{2}{c}{ Decrease in glucose (mg.) } \\
$(\mu$ mol. $)$ & Without factor & With factor \\
0 & 0.400 & 0.727 \\
10 & 0.335 & 0.772
\end{tabular}

Table 15. Effect of the activating factor of muscle (fraction $3 P, 1 \mathrm{mg}$.) on the utilization of adenosinediphosphate $(A D P)$ by brain hexokinase

(ATP, $10 \mu$ mol.; ADP, $20 \mu \mathrm{mol} . / 3 \mathrm{ml}$. Activity of brain hexokinase with $\mathrm{ATP}=100$.)

Brain extract

Brain extract + muscle fraction

\begin{tabular}{|c|c|}
\hline Hexoking & vity \\
\hline ATP & $\mathrm{ADP}$ \\
\hline $\begin{array}{l}100 \\
330\end{array}$ & $\begin{array}{r}75 \\
192\end{array}$ \\
\hline
\end{tabular}

There is no indication for the hypothesis that the activation is due to the removal of an inhibitory reaction product. A preparation of the factor, free of phosphohexokinase activity, did not significantly relieve the inhibition of hexokinase by hexosemonophosphate, although it activated the uninhibited fraction of the enzyme (Table 13). The fact that

\begin{tabular}{|c|c|c|}
\hline \multicolumn{3}{|c|}{ Brain extract + muscle fraction (7 mg.) } \\
\hline $\begin{array}{l}\text { Decrease in } \\
\text { glucose } \\
\text { (mg.) }\end{array}$ & $\begin{array}{c}\text { Inhibition } \\
(\%)\end{array}$ & $\begin{array}{c}\text { Activating } \\
\text { effect } \\
\text { (control =100) }\end{array}$ \\
\hline 0.450 & - & 156 \\
\hline 0.210 & 53 & - \\
\hline 0.082 & 82 & - \\
\hline 0.010 & 98 & - \\
\hline
\end{tabular}

munications. Curtius \& Ohlmeyer saturated their system with every coenzyme of glycolysis known at the time. Since then the coenzyme of phosphoglucomutase, glucose-1:6-diphosphate (Leloir, Trucco, Cardini, Paladini \& Caputto, 1948; Cardini, Paladini, Caputto, Leloir \& Trucco, 1949) and of phosphoglyceric mutase, 2:3-diphosphoglyceric acid (Sutherland, Posternak \& Cori, 1949) have been discovered and it is possible that the effects were due, at least in part, to the presence of one of these compounds.

Various other unidentified factors have been described as stimulating the glycolysis of Lebedew juice (Ohlmeyer, 1941, 1950) or of dried yeast cells (Meyerhof \& Kaplan, 1950), but none of these has as yet been specifically assigned to hexokinase. Moreover, their diffusibility distinguishes them from the activating factor here described which in all probability is a protein.

Lipmann \& Kaplan (1949) refer to a communication of Colowick (1947) which has not been accessible to us. Colowick is reported to have found in crude muscle extract a heat-stable, diffusible organic substance which stabilizes hexokinase, but which is apparently not an essential part of the hexokinase system. Were it not for its diffusibility this factor 
might well be identical with the activator here described.

Vestling, Mylroie, Irish \& Grant (1950) recently found that a liver homogenate which had itself no hexokinase activity increased the activity of brain hexokinase. This observation suggests that the activator of hexokinase is present in liver.

\section{The nature of the activator}

The activating factor of muscle seems to be associated with a protein complex which also contains an active ATP-ase, adenylic deaminase, hexokinase and phosphohexokinase. The methods previously used for the preparation of these enzymes (Kielley \& Meyerhof, 1948; Humphrey \& Humphrey, 1950; Schmidt, 1928; Racker, 1947) are similar to those yielding the activating factor. According to Kielley \& Meyerhof (1950) the soluble ATP-ase of muscle is a lipoprotein and it would be interesting to know if the same is true of other components of the complex.

In spite of their initial association the activating factor is independent of the activities of ATP-ase, adenylic deaminase, hexokinase or phosphohexokinase. This conclusion is based not only on the effects of heat treatment which, while destroying enzyme activities, does not greatly impair the function of the activating factor, but also on the lack of correlation in their occurrence which became apparent on further fractionation. Thus it was possible to obtain fractions containing the activator, but having little or no activity with respect to any one or more of these four enzymes, while others were devoid of activating effects, but possessed strong ATP-ase or adenylic deaminase activity. So far, however, whenever either hexokinase or phosphohexokinase activity was found, the activating factor was present as well. This raises the question whether the activator is identical with, or a fragment of, inactivated hexokinase or phosphohexokinase. Such a supposition practically amounts to assuming the existence of a prosthetic group or coenzyme, for which there is at present no evidence. Furthermore, when purified yeast hexokinase was inactivated by heating at $60^{\circ}$ and added to brain extract, no activation was observed.

\section{The mechanism of the activating effect}

We know at present of only three participants in the hexokinase reaction, namely hexose, ATP and enzyme. The activating effect must be due to the interaction, directly or indirectly, of the activator with one of the three reaction partners. Reasons have been given (Weil-Malherbe \& Bone, 1951b) why it must be considered unlikely that the activation of hexokinase can be explained by a resynthesis of ATP, due to myokinase action or another mechanism, and in this paper it is shown that purified myokinase itself has no activating effect under our conditions. An activation of a transphosphorylation mechanism is improbable for the further reason that the factor is specific for hexokinase and has no effect on phosphohexokinase.

An activation of hexoses, however, is well within the bounds of possibility. It has been shown by Gottschalk (1947; see also Slein et al. 1950) that the active form of fructose which is alone able to react with yeast hexokinase has the furanose structure. The suggestion has been made (cf. Bouckaert \& de Duve, 1947) that in the case of glucose, too, it is the furanose and not the pyranose form which is phosphorylated. A catalyst may be envisaged which accelerates the establishment of the equilibrium between furanose and pyranose forms. We have tried to demonstrate a direct influence of the activator on the configuration of glucose by incubating glucose with a muscle-extract fraction. After deproteinization the pretreated glucose reacted with brain hexokinase at exactly the same rate as untreated glucose. This negative result does not, however, disprove the theory, since an effect can only be expected when the equilibrium is continuously disturbed by the removal of the furanose compound.

There is finally the possibility that the factor acts on the enzyme itself. In the first paper of this series it has been shown that unspecific protective agents, such as proteins and other colloids, - $\mathrm{SH}$ compounds, amino-acids and substances which form heavy-metal complexes did not activate brain hexokinase. The evidence reported in the second and third papers strongly suggests that activity resides in a highly active protein of specific properties. Its function is probably more than a mere stabilization of the enzyme, which showed no sign of rapid inactivation under our conditions; the effects which have been described should, therefore, not be confused with the unspecific protective effects of insulin and other proteins on crystalline yeast hexokinase in high dilution (Berger, Slein, Colowick \& Cori, 1946).

The existence of a factor acting directly on the hexokinase molecule would be of particular interest in connexion with the problem of the hormonal control of hexokinase activity. Attempts to demonstrate hormonal influences on hexokinase have been less uniformly successful when tissue extracts, instead of intact tissues such as rat diaphragm, were used. In particular, no direct activating effect of insulin on hexokinase has been found in extracts, though such an effect must be postulated in view of the results obtained with diaphragms of hypophysectomized and hypophysectomized-adrenalectomized rats (Krahl \& Park, 1948; Perlmutter \& Greep, 1948; Bornstein \& Nelson, 1948; Villee \& Hastings, 1949). This discrepancy might be due to the intervention of other factors mediating between 
insulin and hexokinase. The observations of Stadie, Haugaard, Marsh \& Hills (1949) on the rapid reaction of insulin with a constituent of rat diaphragm point in this direction.

Further speculation seems useless in the present state of our knowledge, and the question whether the activator of hexokinase is concerned with the pyranose-furanose conversion or is a member of a hypothetical chain of factors connected with hormonal control must be left open.

\section{SUMMARY}

1. A non-diffusible activator of hexokinase, similar to or identical with that present in erythrocytes, was found in rabbit-muscle extracts. It was partially purified by fractionation with ammonium sulphate or by isoelectric precipitation at pH 5.6.

2. The activator is associated with an enzyme complex containing adenosinetriphosphatase, adenylic deaminase, hexokinase, and phosphohexokinase. Further fractionation showed, however, that the activator is not correlated with the activity of any particular one of these four enzymes. Moreover, they could be differentially inactivated by a degree of heating which did not materially impair the function of the activator.

3. On addition of increasing quantities of acti- vator to rat-brain hexokinase the effect reaches a saturation value. With our more active preparations the addition of $0.5-1.0 \mathrm{mg} . / 3 \mathrm{ml}$. was required for maximum effect.

4. The activator is fairly heat-stable, though less so than the erythrocyte factor. After coagulation the activity is contained in the supernatant from which it can be removed by deproteinization.

5. Purified myosin or myokinase had no activating effect on hexokinase.

6. The activator is specific for hexokinase, but does not affect phosphohexokinase. On the other hand, hexokinase activity is increased whether glucose or fructose is the substrate, whether the enzyme is derived from brain, muscle or yeast and whether it is crude or partially purified.

7. A study of the end products of the reaction offered no explanation for the activating effect. In particular, no indication was found that the effect was due to the removal of inhibitory reaction products.

8. The mechanism of the activation is discussed and two hypotheses are considered: (1) that the activator acts by catalysing the conversion of hexopyranose to hexofuranose; (2) that the activator acts directly on the hexokinase molecule, possibly as a member of a chain of factors mediating between hormones and enzyme.

\section{REFERENCES}

Bailey, K. (1942). Biochem. J. 36, 121.

Berger, L., Slein, M. W., Colowick, S. P. \& Cori, C. F. (1946). J. gen. Physiol. 29, 379.

Bornstein, J. \& Nelson, J. F. (1948). Nature, Lond., 162, 572. Bouckaert, J. P. \& de Duve, C. (1947). Physiol. Rev. 27, 39. Cardini, C. E., Paladini, A. C., Caputto, R., Leloir, L. F. \& Trucco, R. E. (1949). Arch. Biochem. 22, 87.

Colowick, S. P. (1947). 112th Meeting Amer. chem. Soc. Abstr. 57 C.

Colowick, S. P. \& Kalckar, H. M. (1943). J. biol. Chem. 148, 117.

Curtius, L. \& Ohlmeyer, P. (1938). Biochem. Z. 298, 412.

Folin, O. \& Ciocalteu, V. (1927). J. biol. Chem. 73, 627.

Gottschalk, A. (1947). Biochem. J. 41, 478.

Humphrey, B. A. \& Humphrey, G. F. (1950). Biochem. J.47, 238.

Kalckar, H. M. (1947). J. biol. Chem. 167, 461.

Kielley, W. W. \& Meyerhof, O. (1948). J. biol. Chem. 176, 591.

Kielley, W. W. \& Meyerhof, O. (1950). J. biol. Chem. 183, 391.

Krahl, M. E. \& Park, C. R. (1948). J. biol. Chem. 174, 939.

Leloir, L. F., Trucco, R. E., Cardini, C. E., Paladini, A. \& Caputto, R. (1948). Arch. Biochem. 19, 339.
Lipmann, F. \& Kaplan, N. O. (1949). Ann. Rev. Biochem.18, 267.

Meyerhof, O. \& Kaplan, A. (1950). Arch. Biochem. 28, 147. Meyerhof, O. \& Wilson, J. R. (1948). Arch. Biochem. 17, 153. Nelson, N. (1944). J. biol. Chem. 158, 375.

Ohlmeyer, P. (1941). Hoppe-Seyl. Z. 267, 264.

Ohlmeyer, P. (1950). Fed. Proc. 9, 210.

Perlmutter, M. \& Greep, R. O. (1948). J. biol. Chem. 174, 915.

Racker, E. (1947). J. biol. Chem. 167, 843.

Schmidt, G. (1928). Hoppe-Seyl. Z. 179, 243.

Slein, M. W., Cori, G. T. \& Cori, C. F. (1950). J. biol. Chem. 186, 763.

Stadie, W. C., Haugaard, N., Marsh, J. B. \& Hills, A. G. (1949). Am. J. med. Sci. 218, 265, 275.

Sutherland, E. W., Posternak, T. Z. \& Cori, C. F. (1949). J. biol. Chem. 179, 501.

Vestling, C.S., Mylroie, A. K., Irish, U. \& Grant, N. H. (1950). J. biol. Chem. 185, 789.

Villee, C. A. \& Hastings, A. B. (1949). J. biol. Chem. 179, 673.

Weil-Malherbe, H. \& Bone, A. D. (1951 a). Biochem. J. 49, 339.

Weil-Malherbe, H. \& Bone, A. D. (1951 b). Biochem. J. 49, 348. 